\title{
Design of Fire-resistant Concrete Structures
}


Downloaded by [] on [26/04/23]. Copyright @ ICE Publishing, all rights reserved. 


\section{Design of Fire-resistant Concrete Structures}

\section{Kristian Dahl Hertz}

Technical University of Denmark 
Published by ICE Publishing, One Great George Street, Westminster, London SW1P 3AA.

Full details of ICE Publishing representatives and distributors can be found at: www.icebookshop.com/bookshop_contact.asp

\section{Other titles by ICE Publishing:}

Structural Fire Engineering

Tom Lennon. ISBN 978-0-7277-4141-7

Handbook of Tunnel Fire Safety, Second edition

Alan Beard and Richard Carvel. ISBN 978-0-7277-4153-0

Designers' Guide to EN 1992-1-1 and EN 1992-1-2 Eurocode 2: Design of Concrete Structures. General rules and rules for buildings and structural fire design

R S Narayanan and A Beeby. ISBN 978-0-7277-3105-0

www.icebookshop.com

A catalogue record for this book is available from the British Library

ISBN 978-0-7277-6444-7

(c) Thomas Telford Limited 2019

ICE Publishing is a division of Thomas Telford Ltd, a wholly-owned subsidiary of the Institution of Civil Engineers (ICE).

All rights, including translation, reserved. Except as permitted by the Copyright, Designs and Patents Act 1988, no part of this publication may be reproduced, stored in a retrieval system or transmitted in any form or by any means, electronic, mechanical, photocopying or otherwise, without the prior written permission of the Publisher, ICE Publishing, One Great George Street, Westminster, London SW1P 3AA.

This book is published on the understanding that the author is solely responsible for the statements made and opinions expressed in it and that its publication does not necessarily imply that such statements and/or opinions are or reflect the views or opinions of the publishers. While every effort has been made to ensure that the statements made and the opinions expressed in this publication provide a safe and accurate guide, no liability or responsibility can be accepted in this respect by the author or publishers.

While every reasonable effort has been undertaken by the author and the publisher to acknowledge copyright on material reproduced, if there has been an oversight please contact the publisher and we will endeavour to correct this upon a reprint.

Cover photo: The Sphinx Building at Iceland's Wharf, Copenhagen using SL-decks with 240 min fire resistance (C Kristian Dahl Hertz).

Commissioning Editor: James Hobbs

Production Editor: Madhubanti Bhattacharyya

Marketing Specialist: April Asta Brodie

Typeset by The Manila Typesetting Company

Index created by Matthew Gale

Printed and bound in Great Britain by TJ International, Padstow 


\section{Contents}

About the author

vii

Notation

Introduction

01

Materials

1.1. Fire-exposed materials

1.2. Concrete

1.3. Thermal properties 28

1.4. Reinforcement 31

References

02

\section{Fire exposure}

2.1. Fire

2.2. Temperature movement

2.3. Temperature calculation

References

03

\section{Structural impact}

3.1. Fire safety design

3.2. Stress distribution

3.3. Anchorage

04

\section{Design methods}

4.1. Beams

4.2. Slabs

4.3. Columns

4.4. Walls

4.5. Connections and frames

4.6. Explosive spalling

4.7. Tunnels

References

5.2. Slabs

5.3. Columns

5.4. Walls

6.1. Beams

6.2. Slabs

6.3. Columns

6.4. Walls 
6.5. Connections and frames 231

6.6. Explosive spalling 231

6.7. Tunnels 232

Reference 232

Index 233 


\section{About the author}

Kristian Dahl Hertz MSc, PhD is a professor in the design of building structures at the Department of Civil Engineering at the Technical University of Denmark (DTU). He has also a background in firefighting as a lieutenant of the reserve in civil defence and as a part-time consulting engineer for M. Folmer Andersen Ltd. Here, he designed building structures for the Ministry of Foreign Affairs of Saudi Arabia, the Royal Theatre in Copenhagen, the National Bank of Iraq, the Parliament of Greenland, factories and domestic buildings.

Kristian began teaching in structural fire safety design at DTU in 1978 and, for 16 years, was a regular visiting professor at London City University. After completing his PhD (Properties of Fire Exposed Concrete) in 1980, he became a part-time associate professor and started developing methods for the design of fire-resistant concrete structures, which is the subject of this book.

In 1999 he completed a Master's degree in Fire Safety at DTU. Throughout the 1990s he also served as a head of department and merged 14 small DTU departments into the Department of Civil Engineering. At the same time, he was active in code writing and implemented some of the methods for designing concrete structures for fire exposure in the Danish and European codes.

In 2009, Kristian invented super-light structures and pearlchain technology. These light and fire-resistant concrete structures are now applied in a number of countries. 
Downloaded by [] on [26/04/23]. Copyright @ ICE Publishing, all rights reserved. 
area of openings of a compartment

area of opening $i$

area of concrete cross-section

$A_{\text {tot }}$

area of steel cross-section

$a$

total enclosing surface area of a compartment

$a$

thermal diffusivity

parameter proportional to $\varepsilon_{\mathrm{c}}$

$a_{\mathrm{c}} \quad$ damaged zone of a cross-section

$a_{\mathrm{o}}$

$a$ for $\varepsilon_{\mathrm{o}}$ instead of $\varepsilon_{\mathrm{c}}$

$a_{\mathrm{u}}$

ultimate value of $a$

$B$

coefficient of total deflection

$B_{\mathrm{f}}$

$b$

width of flange of T-shaped cross-section

$b_{\mathrm{o}}$

C

C

C

$C_{\text {eff }}$

C'

$C_{i}$

$c$

$c_{\mathrm{c}}$

thermal inertia

$b$ for $a=a_{\mathrm{o}}$

thickness of cross-section

thickness of cover

arbitrary constant

effective width $\left(=\eta^{4 / 3} C\right)$

half period of a fire heat pulse

constant of number $i$

reduced thickness of cross-section

cover thickness

$c_{\mathrm{p}}$

heat capacity

$D^{\prime}$

thermal amplitude

$D_{\mathrm{s}}$

$d$

diameter of reinforcing steel

$d_{\mathrm{c}}$

$d_{\mathrm{g}}$

$d_{N}$

$d_{P}$

$d_{P+N}$

$d_{\mathrm{s}}$

$d_{\mathrm{s}, \mathrm{ave}}$

$d_{\mathrm{s}}$

$\mathrm{d} r$

E

depth of insulation on a cross-section

depth of force of compression zone

distance to centre of gravity from compressed

edge

depth of normal force $N$

depth of prestressing force $P$

depth of the resultant of $P$ and $N$

depth of steel reinforcement

average of $d_{\mathrm{s}}$

depth of steel opposite the steel at $d_{\mathrm{s}}$ increment of radial coordinate modulus of elasticity (E-modulus)

E'

constant temperature of a fire

$E_{\mathrm{c}} \quad$ E-modulus of concrete

$E_{0} \quad$ initial tangent modulus

$E_{\mathrm{c} 0}$

initial tangent modulus of concrete

$E_{\mathrm{c} 020}$

$E_{\mathrm{c} 0}$ at $20^{\circ} \mathrm{C}$

$E_{\mathrm{c} 20}$

$E_{\mathrm{c}}$ at $20^{\circ} \mathrm{C}$

$E_{\mathrm{cM}}$

E-modulus of concrete at the midpoint 


\begin{tabular}{|c|c|}
\hline$E_{\mathrm{P}}$ & tangent modulus of a prestressed steel \\
\hline$E_{\mathrm{s}}$ & E-modulus of steel \\
\hline$E_{\mathrm{s} 20}$ & $E_{\mathrm{s}}$ at $20^{\circ} \mathrm{C}$ \\
\hline$E A_{\mathrm{c}}$ & axial stiffness of concrete section \\
\hline$E A_{\mathrm{s}}$ & axial stiffness of steel section \\
\hline$E I_{\mathrm{c}}$ & flexural stiffness of concrete section \\
\hline$E I_{\mathrm{s}}$ & flexural stiffness of steel section \\
\hline$e$ & eccentricity \\
\hline$e_{\text {load }}$ & eccentricity of applied load \\
\hline$e_{\text {th }}$ & thermal eccentricity including transience \\
\hline$e_{\mathrm{tr}}$ & $\begin{array}{l}\text { additional eccentricity from transient thermal } \\
\text { expansion }\end{array}$ \\
\hline$F$ & force \\
\hline$F_{\mathrm{c}}$ & force of a concrete cross-section \\
\hline$F_{\mathrm{cE}}$ & Euler force of a concrete column \\
\hline$F_{\text {cr }}$ & critical force \\
\hline$F_{\text {crc }}$ & $F_{\text {cr }}$ of a plain concrete column \\
\hline$F_{\text {cu }}$ & ultimate force of a concrete cross-section \\
\hline$F_{\mathrm{E}}$ & $\begin{array}{l}\text { Euler force (column strength with elastic } \\
\text { working curve) }\end{array}$ \\
\hline$F_{\text {load }}$ & force load \\
\hline$F_{\mathrm{R}}$ & $\begin{array}{l}\text { Rankine force (column strength with curved } \\
\text { working curve) }\end{array}$ \\
\hline$F_{\mathrm{s}}$ & force of a steel cross-section \\
\hline$F_{\mathrm{sE}}$ & Euler force of a steel column \\
\hline$F_{\text {su }}$ & ultimate force of a steel cross-section \\
\hline$F_{\mathrm{u}}$ & ultimate force of a cross-section \\
\hline$F_{\mathrm{w}}$ & force in web of a T-shaped cross-section \\
\hline$f$ & strength \\
\hline$f_{\mathrm{cc}}$ & compressive strength of concrete \\
\hline$f_{\text {cc,ave }}$ & average of $f_{\mathrm{cc}}$ \\
\hline$f_{\mathrm{cc} 20}$ & concrete compressive strength at $20^{\circ} \mathrm{C}$ \\
\hline$f_{\mathrm{cM}}$ & compressive strength of concrete at midpoint \\
\hline$f_{\mathrm{ct}}$ & tensile strength of concrete \\
\hline$f_{\text {ct } 20}$ & $f_{\text {ct }}$ at $20^{\circ} \mathrm{C}$ \\
\hline$f_{\mathrm{s}}$ & tensile strength of idealised steel \\
\hline$f_{\mathrm{s} 20}$ & $f_{\mathrm{s}}$ at $20^{\circ} \mathrm{C}$ \\
\hline$f_{\mathrm{su}}$ & ultimate tensile stress of steel \\
\hline$f_{\mathrm{sy}, \theta}$ & so-called 'effective yield strength' \\
\hline$f_{\mathrm{u}}$ & ultimate stress \\
\hline$f_{\alpha \mathrm{c}}$ & $\begin{array}{l}\text { concrete compressive strength at an angle } \alpha \text { to } \\
\text { a reinforcing bar }\end{array}$ \\
\hline$f_{0 \cdot 2}$ & $0 \cdot 2 \%$ proof stress \\
\hline$H$ & height of cross-section \\
\hline$h$ & reduced height of cross-section \\
\hline
\end{tabular}




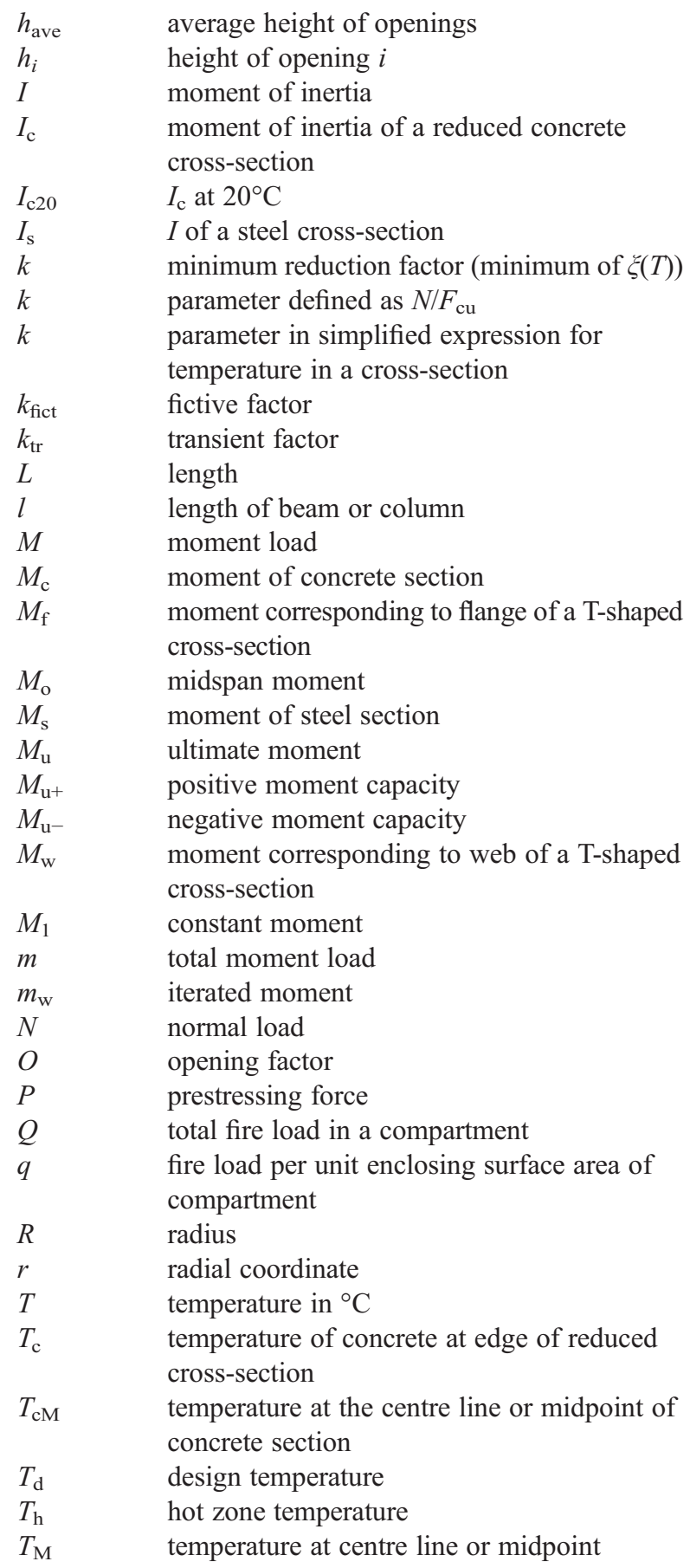




\begin{tabular}{|c|c|}
\hline$T_{\mathrm{s}}$ & steel temperature \\
\hline$T_{\mathrm{s} \text {,ave }}$ & average $T_{\mathrm{s}}$ \\
\hline$T_{1}-T_{10}$ & $\begin{array}{l}\text { temperatures at wood crib row } 1-10 \text { from } \\
\text { bottom in long compartment }\end{array}$ \\
\hline$T_{1}-T_{64}$ & $\begin{array}{l}\text { parameters describing a damage curve } \xi(T) \\
\text { for a material }\end{array}$ \\
\hline$t$ & time \\
\hline$t_{\mathrm{d}}$ & time of end of heating \\
\hline$u$ & midspan deflection of a column \\
\hline$V$ & shear force \\
\hline$V_{\mathrm{c}}$ & $\begin{array}{l}\text { shear force with respect to concrete in } \\
\text { compression }\end{array}$ \\
\hline$V_{\text {ct }}$ & shear force with respect to concrete in tension \\
\hline$V_{\mathrm{s}}$ & shear force with respect to the steel links \\
\hline $\mathrm{v}_{\mathrm{TR}}$ & speed of temperature increase in a cylinder \\
\hline$W$ & $\begin{array}{l}\text { width of one-sided exposed cross-section or } \\
\text { width of half of a two-sided exposed } \\
\text { cross-section }\end{array}$ \\
\hline$W_{\mathrm{f}}$ & thickness of flange \\
\hline$W_{i}$ & width of side $i$ \\
\hline$W_{\mathrm{w}}$ & width of half web \\
\hline$w_{i}$ & width of opening $i$ \\
\hline$x$ & depth of the neutral axis \\
\hline$x, y, z$ & coordinates \\
\hline$y$ & depth of compression zone \\
\hline$\alpha$ & angle \\
\hline$\Gamma$ & $\begin{array}{l}\text { factor for fully developed fire depending on } b \\
\text { and } O\end{array}$ \\
\hline$\delta$ & deflection \\
\hline$\delta_{\mathrm{u}}$ & ultimate deflection \\
\hline$\varepsilon$ & strain \\
\hline$\varepsilon_{\mathrm{o}}$ & concrete strain at minimum compressed edge \\
\hline$\varepsilon_{\mathrm{c}}$ & concrete strain at maximum compressed edge \\
\hline$\varepsilon_{\text {creep }}$ & creep strain of concrete \\
\hline$\varepsilon_{\mathrm{cu}}$ & ultimate concrete strain at stress $f_{\mathrm{cc}}$ \\
\hline$\varepsilon_{\text {cup }}$ & ultimate plastic strain of concrete $\left(>\varepsilon_{\mathrm{cu}}\right)$ \\
\hline$\varepsilon_{\mathrm{cu} 20}$ & $\varepsilon_{\mathrm{cu}}$ at $20^{\circ} \mathrm{C}$ \\
\hline$\varepsilon_{\text {load }}$ & instantaneous stress-related concrete strain \\
\hline$\varepsilon_{\mathrm{p}}$ & steel strain at prestress \\
\hline$\varepsilon_{\mathrm{s}}$ & steel strain \\
\hline$\varepsilon_{\mathrm{smin}}$ & minimum $\varepsilon_{\mathrm{s}}$ to obtain stress $f_{\mathrm{s}}$ \\
\hline$\varepsilon_{\text {sy }}$ & yield strain of steel \\
\hline$\varepsilon_{\text {th }}$ & thermal strain \\
\hline$\varepsilon_{\text {th,ave }}$ & average $\varepsilon_{\text {th }}$ \\
\hline$\varepsilon_{\mathrm{tr}}$ & transient strain \\
\hline
\end{tabular}




\begin{tabular}{|c|c|}
\hline$\eta$ & stress-distribution factor \\
\hline$\eta_{\mathrm{f}}$ & stress-distribution factor of flange \\
\hline$\eta_{\mathrm{w}}$ & stress-distribution factor of web \\
\hline & inclination of compression stresses \\
\hline & curvature \\
\hline reep & $\kappa$ caused by creep \\
\hline oad & $\kappa$ caused by $\varepsilon_{\text {load }}$ \\
\hline$\kappa_{\mathrm{th}}$ & thermal curvature \\
\hline$\kappa_{\mathrm{tr}}$ & $\kappa$ caused by $\varepsilon_{\mathrm{tr}}$ \\
\hline & conductivity \\
\hline$v$ & Poisson's ratio or shear effectiveness factor \\
\hline$v_{20}$ & Poisson's ratio at $20^{\circ} \mathrm{C}$ \\
\hline & strength reduction \\
\hline$\xi_{\mathrm{c}}$ & reduction of $f_{\mathrm{cc}}$ due to heating \\
\hline$\xi_{\mathrm{ccCOLD}}$ & reduction of $f_{\mathrm{cc}}$ in a COLD condition \\
\hline$\xi_{\mathrm{ccHOT}}$ & reduction of $f_{\mathrm{cc}}$ in a HOT condition \\
\hline & $\xi_{\mathrm{c}}$ at centre line of a cross-section \\
\hline$\xi_{\mathrm{cMf}}$ & $\xi_{\mathrm{c}}$ at top of a flange of a T-shaped cross-section \\
\hline$\xi_{\mathrm{cMw}}$ & $\begin{array}{l}\xi_{\mathrm{c}} \text { at centre line of a web of a T-shaped } \\
\text { cross-section }\end{array}$ \\
\hline$\xi_{\text {ccrapid }}$ & reduction in $f_{\mathrm{cc}}$ due to rapid heating \\
\hline & reduction of $f_{\text {ct }}$ due to heating \\
\hline & reduction of $f_{\mathrm{s}}$ \\
\hline$\xi_{\mathrm{s}, \text { ave }}$ & average $\xi_{\mathrm{s}}$ \\
\hline$\xi_{\mathrm{s} 0 \cdot 2}$ & reduction of yield strength or $0 \cdot 2 \%$ strength \\
\hline$\xi_{\mathrm{s} 2 \cdot 0}$ & reduction of $2 \cdot 0 \%$ ultimate strength \\
\hline$\xi_{\mathrm{scw}}$ & yield strength reduction for cold-worked steel \\
\hline$\xi_{\text {scwC }}$ & $\begin{array}{l}\text { yield strength reduction for cold-worked steel } \\
\text { after cooling }\end{array}$ \\
\hline$\xi_{\mathrm{scw} 0 \cdot 2}$ & $0 \cdot 2 \%$ strength reduction for cold-worked steel \\
\hline & $\begin{array}{l}\text { ultimate strength reduction for cold-worked } \\
\text { steel }\end{array}$ \\
\hline$\xi_{\mathrm{scw} 2 \cdot 0 \mathrm{C}}$ & $\begin{array}{l}\text { ultimate strength reduction for cold-worked } \\
\text { steel after cooling }\end{array}$ \\
\hline$\xi_{\mathrm{sp}}$ & yield strength reduction for prestressing wire \\
\hline$\xi_{\mathrm{spC}}$ & $\begin{array}{l}\text { yield strength reduction for prestressing wire } \\
\text { after cooling }\end{array}$ \\
\hline$\xi_{\mathrm{sp} 2 \cdot 0}$ & $\begin{array}{l}\text { ultimate strength reduction for prestressing } \\
\text { wire }\end{array}$ \\
\hline$\xi_{\mathrm{sp} 2 \cdot 0 \mathrm{C}}$ & $\begin{array}{l}\text { ultimate strength reduction for prestressing } \\
\text { wire after cooling }\end{array}$ \\
\hline$\xi_{\mathrm{sq}}$ & $\begin{array}{l}\text { yield strength reduction of quenched and } \\
\text { self-tempered steel }\end{array}$ \\
\hline$\xi_{\mathrm{sqC}}$ & $\begin{array}{l}\text { yield strength reduction of quenched and } \\
\text { self-tempered steel after cooling }\end{array}$ \\
\hline
\end{tabular}




\begin{tabular}{|c|c|}
\hline$\xi_{\mathrm{sq} 2 \cdot 0}$ & $\begin{array}{l}\text { ultimate strength reduction of quenched and } \\
\text { self-tempered steel }\end{array}$ \\
\hline$\xi_{\mathrm{sq} 2 \cdot 0 \mathrm{C}}$ & $\begin{array}{l}\text { ultimate strength reduction of quenched and } \\
\text { self-tempered steel after cooling }\end{array}$ \\
\hline$\rho$ & density \\
\hline$\sigma$ & stress \\
\hline$\sigma_{\mathrm{c}}$ & concrete stress at maximum compressed edge \\
\hline$\sigma_{\mathrm{cT}}$ & transverse compressive stress \\
\hline$\sigma_{\mathrm{o}}$ & concrete stress at minimum compressed edge \\
\hline$\sigma_{\mathrm{p}}$ & prestress of steel \\
\hline$\sigma_{\mathrm{s}}$ & stress of steel \\
\hline$\sigma_{\mathrm{v}}$ & vertical stress \\
\hline$\tau$ & shear stress \\
\hline$\tau_{\text {bond }}$ & bond stress \\
\hline$\tau_{\mathrm{fp}}$ & $\begin{array}{l}\text { bond strength of smooth wire related to } \\
\text { cylinder strength }\end{array}$ \\
\hline$\tau_{\mathrm{fz}}$ & $\begin{array}{l}\text { bond strength of embossed wire related to } \\
\text { cylinder strength }\end{array}$ \\
\hline$\tau_{\mathrm{p}}$ & $\begin{array}{l}\text { bond strength of prestressing wire with } \\
\text { smooth strands }\end{array}$ \\
\hline$\tau_{\mathrm{z}}$ & $\begin{array}{l}\text { bond strength of prestressing wire with } \\
\text { embossed strands }\end{array}$ \\
\hline$v$ & effectiveness factor for shear \\
\hline \multicolumn{2}{|l|}{ Indices } \\
\hline ave & average \\
\hline B & bottom of slab \\
\hline $\mathrm{C}$ & cold condition (after a fire) \\
\hline COLD & cold condition \\
\hline c & concrete \\
\hline $\mathrm{cc}$ & concrete compression \\
\hline $\mathrm{cE}$ & concrete Euler \\
\hline $\mathrm{cM}$ & concrete at midpoint \\
\hline $\mathrm{cr}$ & critical \\
\hline $\mathrm{cT}$ & concrete transverse \\
\hline ct & concrete tension \\
\hline $\mathrm{cu}$ & concrete ultimate \\
\hline $\mathrm{cw}$ & cold-worked \\
\hline $\mathrm{E}$ & Euler \\
\hline eff & effective \\
\hline f & flange \\
\hline fict & fictive \\
\hline HOT & hot condition (during a fire) \\
\hline$i$ & number \\
\hline M & midpoint of cross-section \\
\hline
\end{tabular}


$\mathrm{pq}$

prestressing

quenched and tempered prestressing steel quenched and self-tempered slack reinforcement

R

Rankine

S steel

$\mathrm{sE}$

steel Euler

$\mathrm{su}$

steel ultimate

sy

steel yield

top of slab

thermal

transient

ultimate

vertical

web

initial

$0 \cdot 2 \%$ proof (stress)

$0 \cdot 2$

20

at $20^{\circ} \mathrm{C}$

positive

negative 
Downloaded by [] on [26/04/23]. Copyright @ ICE Publishing, all rights reserved. 
Dear reader, difficult matters do not exist - only bad explanations.

Many consider the nature of fire-exposed concrete structures hard to understand. The aim of this book is to present this subject so that you understand all aspects fully and will be able to design fire-resistant concrete structures efficiently. The book introduces chemical and physical properties in Chapter 1 on materials and Chapter 2 on fire exposure. Based on this, methods for describing the impact of fire on structures are derived in Chapter 3 and logical design methods are presented in Chapter 4. Chapter 5 provides calculation examples and shows how to apply the design methods in context. Finally, a design guide is presented in Chapter 6 - this is where practical engineers can find the methods needed when designing a fire-resistant concrete structure.

So that you can easily find the background for a certain formula and find a calculation example demonstrating its use, the sections in Chapter 4 (which presents the derivation and explanation of design methods), Chapter 5 (containing calculation examples) and Chapter 6 (the design guide) are numbered as equivalents. For example, Section 4.1.4 T-shaped and ribbed beams in Chapter 4 explains the design methods and derives the formulas for T-shaped beams. The similarly numbered Section 5.1.4 in Chapter 5 provides a calculation example for a T-shaped beam and Section 6.1.4 in Chapter 6 presents the formulas and methods needed for the design.

The author used to say to his students that when you know where you are, and know where you come from, you can better see where you are going. History contributes to understanding of present developments. Therefore, as far as possible, this book refers to the first findings on the subjects dealt with.

When the author graduated in the 1970s, engineers designed concrete structures for the ultimate limit state and for service load by well-documented design methods. However, when they documented fulfilment of fire safety requirements, they only had rules of thumb and random experience as a basis for the assessments.

Since fire safety considerations are decisive for the design of roughly a third of all structures for concrete buildings and 
tunnels, the author decided to contribute to research on the subject in order to establish a rational basis for engineering design. He completed a $\mathrm{PhD}$ on the properties of fire-exposed concrete structures in 1980 (Hertz, 1980a, 1980b, 1980c).

The $\mathrm{PhD}$ project concerned the properties of concrete at elevated temperatures and a new method for heating concrete rapidly without thermal gradients by means of microwave power. It also presented data for the anchorage capacity of reinforcement and a new test method for measuring it, and it presented about 500 references on the subject of fire-exposed concrete structures.

The external examiner for the author's $\mathrm{PhD}$ was Professor Ove Pettersson. He was head of a fire research group at Lund University, Sweden, that had carried out comprehensive work on the fire safety of steel structures (Magnusson et al., 1974; Pettersson et al., 1976) and some work on reinforcement for concrete structures (Anderberg, 1978, 1988). However, the Swedish government changed priorities from structural fire research to rescue-related research and this meant that the group was not able to continue the work.

In the following years, the author therefore conducted a series of projects at the Technical University of Denmark, establishing design methods for fire-exposed concrete structures and publishing the results in nine reports for the international group CIB W14, including the publication first introducing the reduced cross-section method (Hertz, 1985).

The author further developed the design methods and documented the results of a number of research projects, students' theses and experience from application of the methods in practice as a consulting engineer. He reported some of the data and methods in journal papers and, of course, in teaching. As a member of the project team writing the fire part of EN 1992-1-2: Eurocode 2 (CEN, 2002), he introduced some of the design methods in that code.

This book presents design methods and data for fire-resistant concrete structures as a whole in order to facilitate their application in practice and provide engineers with sufficient background knowledge to understand them.

The book's aim is thus as follows: you should be able to design any structure made of any concrete to resist load at any time of any fire exposure. 


\section{REFERENCES}

Anderberg Y (1978) Armeringsståls mekaniska egenskaper vid höga temperaturer (Mechanical Properties of Reinforcement at High Temperatures). Department for Building Constructions, Technical University of Lund, Lund, Sweden. (In Swedish.)

Anderberg Y (1988) Mechanical properties of reinforcement at high temperatures. Fire Safety Journal 13: 17-26.

CEN (Comité Européen de Normalisation) (2002) EN 1992-1-2: Eurocode 2: Design of concrete structures - Part 1.2 - General rules - Structural fire design. CEN, Brussels, Belgium.

Hertz KD (1980a) Betonkonstruktioners Brandtekniske Egenskaber (Properties of Fire Exposed Concrete Structures). PhD thesis, Institute of Building Design, Technical University of Denmark, Lyngby, Denmark, Parts 1 and 2, Report 140. (In Danish.)

Hertz KD (1980b) Armeringsståls Forankring ved Høje Temperaturer (Anchorage of Reinforcing Steels at High Temperatures). PhD thesis, Institute of Building Design, Technical University of Denmark, Lyngby, Denmark, Part 3, Report 138. (In Danish.)

Hertz KD (1980c) Reference List on Concrete Constructions Exposed to High Temperatures. PhD thesis, Institute of Building Design, Technical University of Denmark, Lyngby, Denmark, Part 4, Report 141 .

Hertz KD (1985) Analyses of Prestressed Concrete Structures Exposed to Fire. Institute of Building Design, Technical University of Denmark, Lyngby, Denmark, Report 174, CIB W14/85/9(DK).

Magnusson SE, Pettersson O and Thor J (1974) Brandteknisk dimensionering av stålkonstruktioner. Swedish Institute of Steel Construction, Stockholm, Sweden, Publikation 38. (In Swedish.)

Pettersson O, Magnusson SE and Thor J (1976) Fire Engineering Design of Steel Structures. Swedish Institute of Steel Construction, Stockholm, Sweden, Bulletin 52, Publication 50. (English translation of Magnusson et al. (1974).) 